$\xi=1$ 圆

\title{
Innovation in Education: Goals and Prospects
}

\author{
O.A. Evreeva ${ }^{*}$ \\ ${ }^{1}$ Department of Philosophy, Russian State Social University, Wilhelm Pieck Street, 4, build.1, Moscow, 129226, Russian Federation \\ *Corresponding author E-mail: evreeva.o.a@mail.ru
}

\begin{abstract}
The focal point of the paper is the study of one of the actual challenges of the modern educational philosophy, i.e., the problem of innovations in education. This point encompasses the definition of targets and prospects describing the development of an educational environment. The focus of the paper is the essence of innovations in an educational process. We proceed from the idea that it is critical to outline the reasons that determine innovations. We believe that they emerge as necessary changes in a traditional educational paradigm and the model of the educational system. Of much importance is the understanding of the goals and the prospects of innovative educational processes. Therefore, we describe the goals, methods and means of modern educational innovation policy. Our major finding is that they stem from global economy's challenges emerging in the conditions of postindustrial society both at global and local levels. Consequently, education, as a unique resource for the development of society, is a subject for transformation of its structure and content. Another important finding is the critical role of innovative education as the major shaper of the relations that will determine the future of our civilization. This future depends on the personality that originates from the new educational system.

The authors' conclusions emerge as a combination of empirical facts from the sphere of Russian and foreign educational experiences, and as the provisions of selected educational concepts and strategies.
\end{abstract}

Keywords: investments in innovations, innovations in the educational sphere, innovation policy, education paradigm, knowledge, functionality, efficiency.

\section{Introduction}

The concepts of knowledge, skills, competencies and innovations are fast becoming key instruments of global economy. In 2004, the distinguished innovation expert K. Laflami attempted to highlight the relevance of the new type of thinking, "We live in the time of restructuring which mainly targets the globalization of markets. The competition among countries is becoming more intense, and enterprises are constantly searching for new products and the new system of production management. New technologies and the formation of labor in such societies begin to play a dominant role ... Education provides workforce experts whose world view focuses on innovation and practical activities with these new technologies" [1].

There is much evidence that in such conditions knowledge, skills, and abilities, as well as the process of their acquisition have become a type of a new economic resource. It plays a critical role as another independent factor of production which often determines the profitability of production itself. Experts believe that modern educational paradigm has undergone a deep change. The result of this change is an initial conceptual scheme with training elements and instruction methods. The scheme emerges as the transformation of an educational system's model. This transformation leads to a set of ways to organize educational processes. And this means that the way of managing the educational system is a subject to revision.

In our research the term "educational system" encompasses "a united integrated single entity, an ordered set of interacting elements specially created for the realization of the social functions of education" [2]. Central to the entire discipline is the idea that the instruction typical of the "heavy manufacturing era" reconceptualizes itself into the postindustrial educational paradigm.
The issue of the paradigm change has long been a question of great interest in a wide range of fields. The old traditional system tends to become more and more transformed. In the West this process is underway for $\mathbf{5 0}$ years, in Russia it is the activity of the decade. The result of this transformation is the concept of "educational services market". The concept stems from the idea to serve, reproduce and transform the economic, social and political infrastructure of society. It assists to respond to the "global challenges" of the time. Experts believe that the core component of these almost global challenges, i.e., globalization, emerges not only from the mechanism for transforming the world into a single system with the help of level integration and unification criteria. It also includes the disclosure of the goals, priorities and values of those who acquire the greatest benefit not only from the "formation" of those very challenges, but also from the answers to them. And the circle of these persons is known, as well as the main goals of their activities. Almost 100 years ago, namely in 1917, in his distinguished work "Imperialism, the Highest Stage of Capitalism", V.I. Lenin skillfully characterized public relations at the highest stage of capitalism. His ideas are as follows, "Capitalism reaches the special stage of development when domineering monopolies and financial capital, as well as the export of capital become of great importance. They stimulate the segmentation of the world by international trusts and the partition of the entire territory of the earth by the largest capitalist countries" [3].

According to V.I. Lenin, the class structure of society, therefore, changes in some ways. The significant aspect of this process is the personalization of financial capital. Consequently, the so-called financial oligarchy emerges. In the developed countries they control the biggest part of national wealth. Over time, the financial oligarchy merges with the bureaucratic apparatus of the state and a 
new stage of capitalist relations develops. This stage is statemonopoly capitalism.

There is evidence that the activities of transnational companies (TNNs) (national in terms of capital, but international in terms of their activities) in the modern world are proof of this. Therefore, the American giant corporations of the chemical, electrical, oil, and automobile industries are the largest TNCs. A primary concern is that they created the extensive network of enterprises in Western Europe, Canada and in several developing countries. To date, TNCs control more than $50 \%$ of world industrial production, $68 \%$ of international trade, $40 \%$ of licenses, patents, know-how markets, and almost $100 \%$ of world trade of raw materials [4]. Their highest ambition is to receive super profits and power. They determine others' goals and values and, if there is a conflict of values, they sacrifice the values of others', not their personal interests.

\section{Problem statement}

The demands of the modern market largely determine the goals, methods and means of state educational policy. And the goals are already quite clear, i.e., the preparation of highly professional single-skilled experts in the field of the latest technologies, informatics, marketing, etc. These professionals can meet the challenges of a global economy in postindustrial epoch. This is the dominant target which emerges from the world market mechanism. This target is of primary importance for education both at the planetary and regional levels. And the educational system responds to these challenges with innovative reforms. These challenges are bound with problems which play a pivotal role. There is a prevalent assumption that modern education is susceptible to a crisis. However, central to the entire discipline is the idea that there is no modern educational crisis. Our central finding is that there is the crisis of thinking, the crisis of personal identification of people who have grown up in other economic and social realities.

The results of our study indicate that for those whose moving into adulthood and formation occurred in the 70-80's of the $20^{\text {th }}$ century in the USSR, education has always seemed to be the process of instruction, upbringing and development of a personality. Eventually, education was a critical instrument to develop a well-educated personality with high moral principles. The essence of such education, according to the Soviet ideals, emerged as an aggregate of socially significant qualities. The realization of these qualities was conducive to the prosperity of the society, the socialist society specifically. It was a fantastic idea, the ultimate conceptualization of social engineering thought, the results of which are still very useful for the most adventurous citizens. Despite the deeply rooted romanticism of the Soviet educational system, of much practical value were its pragmatic aspirations which stemmed from economic expediency. The idea of advanced professional education played a critical role in it. This idea resulted in the creation and development of the Soviet economic base.

There is much evidence that nowadays priorities have changed. The spheres of activity of most gigantic corporations, including state monopolies, operating at labor markets, stem from the development and introduction of modern technologies, that can bring the greatest profit and power. These technologies must meet the serious quality requirements, i.e., they must be functional and effective, easy to use and flexible, reliable, and modifiable. The same criteria of quality, efficiency and functionality, as well as the reliability and modifiability, are relevant for the intending personnel who will create and service these technologies. Targeting the formation and development of such innovative qualities of higher school graduates becomes the vector of transformation of both education and, indirectly, of the society itself. Consequently, education is a unique resource for the development of society, changing its structure and main components. It determines the image of the relationships at the interpersonal level, and at the level of people and nature. These relationships are critical for the future of civilization, based on the personality formed by the new educational system [5]. "It is not so much the storage and transfer of knowledge that is the main task of modern educational system, but the production (generation) and the introduction of new knowledge into public life. It determines the viability of the various forms and levels of this system. It is important to note that new knowledge must satisfy the desires of society based on the idea to meet the needs, and their future destiny will necessarily be associated with the transition from the university theoretical plane to the space of practical application. In this regard, the attributive characteristic of education should be the relationship between educational institutions and the economy, education and society" [6].

Back in 1939, the Austrian economist Josef Alois Schumpeter introduced the term "innovation", so popular today in the scientific community. The scientist declared that the pace of economic development depended directly on the quantity and quality of innovation. If at the macroeconomic level they affect the overall economic growth, then at the microlevel they provide a profit.

The development of the methodological and conceptual foundations of innovation since the end of the last century was conducted mainly by Western sociologists, e.g. V. Lundvall, R. Whitley,

L. Winner. The subject of their research was intra-organizational and interorganizational social interaction in the process of innovation, as well as the importance of socio-economic modeling of the innovation process [7].

It is interesting to note that when it comes directly to innovations in education, they mean, firstly, changes not only in the content of education, but also in the structure of educational institutions, as well as in the technologies of teaching and educational processes, methods and means of teaching. Innovations do not bypass the mechanisms of management.

\section{Methods}

Nowadays educational sphere is a part of economic relations. It functions often not just as an equal economic partner, but as one whose prospects for development (future capitalization) tend to surpass the growth of all other economic niches. Therefore, both financial investments and investments in the form of innovations are equally significant [8].

The researchers of innovations in educational sphere singled out the following levels of innovative instruction:

- innovations at the macrolevel and regional level, affecting overall economic growth;

- innovations at the microlevel (the level of educational organizations), directly providing profit.

The innovations correlate, firstly, with the national reach of the educational sphere and, secondly, with the nature of national impact on it. The wide reach presupposes a highly intensive influence of governmental bodies and less independence of educational institutions, the opposite situation is typical of the narrow reach [9]. The nature of the impact can also be variable, i.e., direct impact implies the use of administrative (directive) measures, the indirect impact stems from economic activities.

This study has identified that the state innovation policy at the macrolevel emerges from targeted investments in the innovation and educational process along with other areas that contribute both to the development of innovative potential and to the creation of an innovative structure. The innovative process at the macrolevel leads to a change in the value and consumer qualities of the product or service, and, therefore, the change in the educatorscustomers' relationships [10][12]. Consequently, it seriously affects the socio-economic relations in the society, even if it stems only from scientific and technical or technological innovations. 
Innovative policies emerging from meaningful structural changes in the educational system, affecting social, economic and cultural components, form a general favorable innovation background. They also create important conditions for innovative development [13].

One of the most significant findings to emerge from this study is that innovations at the regional level primarily target a favorable educational climate. They support those structures, the activities of which are directly related to the promotion of innovations regardless of where they are located.

Another important finding is that innovations at the microlevel stimulate innovative activities directly in educational institutions. The most important parameter at this stage is upgrading of the available educational product, which forms the basis of educational services. Systemic changes in the activity of an educational institution also correlate with innovations in the field of major professional educational programs. They function as complexes to satisfy the educational need for knowledge, skills and abilities specified within the framework of special professional educational standards [14], [15], [16]. And this means that the structure and contents of major professional educational programs are subject to transformation. It is critical not only to assess the set of presented academic disciplines, but also it is necessary to offer enough training material to instruct an intending professional. The most important parameter of innovations at the microlevel is frequently the situation in the regional market, related to an educational institution. Increasing both the level of competition and the degree of saturation with educational products of this market leads to the need to search for new markets, thereby expanding the field of activity of the educational organization.

\section{Discussion}

There is a growing body of literature which classifies innovations in the field of general education. For example, the whole variety of possible changes resulting from innovation are divided into the categories which are as follows.

- Status changes - changes that determine the new place of the educational institution in the market.

- Substantial changes - changes in the content of an educational program.

- Management changes - changes in the forms and methods of educational processes' management.

- Technological changes - changes in methods and the forms of training.

- Organizational changes - changes in the forms of educational process' organization.

In the innovation process of higher education systems there are the forms which are as follows.

- General methodological innovations, i.e., the model of the creation of unconventional universal technologies, e.g., the creation of a distance education model.

- Intrasubject innovations, e.g., the introduction of copyrighted original teaching methods.

- Administrative innovations, e.g., successful decisions of managers of different levels and structures, leading to an increase in the effectiveness of the educational process.

- Managerial innovations, e.g., changing the competencies of the personnel of the educational institution.

- Organizational innovations, e.g., innovations related to changing the structure of an educational institution.

- Technological innovations, e.g., the introduction of new technologies for the implementation of an educational process.

- Ideological innovations, innovations which follow the imperatives of the time, e.g., the widespread courses of computer literacy or English.

Interestingly, one of the most memorable innovations in the field of administrative changes was the introduction of the basic principles of quality management, as well as the principles of the Total Quality Management (TQM). This innovation became an integral part of the management system of higher educational institutions. The existence of such a system today is one of the mandatory accreditation indicators [17].

An example of technological innovation is one of the latest ways of structuring educational and methodological material for activating independent learning or the actualization of distance education of students - the creation of the so-called "cases". This type of technology contributes both to further computerization and to the democratization of a modern education system.

The results of this study indicate that the management of higher education teaching personnel is the part of the corporate culture of universities. Managerial innovations concentrate on teachers' competencies. These innovations also include the change in the overall organizational structure of educational institutions, including both the reorganization of old and the creation of new chairs, laboratories, departments [18].

In modern scientific literature, it is customary to single out the stages of innovative activities which are as follows.

- The opening phase which encompasses the process of forming an innovative concept based on the results of scientific research, both applied and theoretical.

- The stage of invention, as the process of creating a sample of some material or conceptual object.

- The testing phase, i.e., a partial application process with a view to understanding the consequences and results.

- The distribution phase, i.e., the process of widespread adoption.

- The extended use phase, i.e., the period of intensive use.

- The stage of reducing the scale of application, i.e., the process of gradual replacement of old technologies with new ones. This scheme is a simplified version of real innovation in education [19]. As far as the main levels of innovation in the educational environment are concerned, they are as follows:

- A conceptual stage

- An organizational and activity stage

- A scientific and methodical stage

The findings of the paper are the development and the substantiation of educational innovation concept. The research indicates that the conceptual level is an effective essential instrument which is necessary for modern educational environment. At the next level, it is critical to attract specialists and scientific consultants to bring into action innovative implementations and their approbations. At this level, apart from professional educators, a critical role belongs to the material and technical support of innovations, without which the updating process is unthinkable. At the scientific and methodological level, the variational part of the innovation process emerges from the development and the approbation of programs, curricula, teaching and methodological complexes.

Currently, Russia is actively introducing new standards for the educational system, which orient it towards integration into the global educational environment [20]. This process comes along with a cardinal revision not only of the form, but also of the content of an educational process at all its levels and in all its forms, i.e., both general and professional. Supplementary education has also become the field of innovation.

\section{Conclusion}

The paper indicates that even the brief retrospective view of the processes taking place in the educational system is enough to understand the depth of the social and economic transformation of Russian society. Of much importance is the fact that the goals, content, forms, the methods of educational activities, and the ways of managing them follow the changing reality. The reality stems from acceleration and the unpredictability of development, both 
economic and technological, the annual doubling of the information field, the "democratization" of the truth, the freedom of choice, and multitudinous culturalism. There is much evidence that nowadays there is no other choice than continuous renewal and restructuring in a very uncertain direction [21]. Expectations are that an educational system must form a personality that will have flexible thinking and professional mobility, readiness for continuing education, openness, tolerance to the society, and easy adaptability to rapidly changing life circumstances. Other critical qualities are the ability to recognize problems and quickly identify them, to eradicate shortcomings, and to generate new ideas. It is the imperative of the time to think creatively, to have the skills of working with ever-growing information, analyzing it and using for personal purposes. Simultaneously, a modern professional expert should be communicative, a perfect team worker, subordinating one's own ego to a common goal and so on ad infinitum.

It seems that the need for a professional expert who pursues his own values, ideals, feelings, convictions, and freedoms will gradually subside because of economic expediency. Less expensive and more manageable subjects of labor relations are sure to prevail over independent professionals. But this is a subject of a further research.

\section{References}

[1] Laflami K (2004), Analiz paradigm obrazovaniia \Sotsiologiia obrazovaniia: teorii, issledovaniia, problem. Kazan, pp: 37.

[2] Voronina EV (2008), Innovatsionnyi proekt obrazovatelnogo uchrezhdeniia: opyt opisaniia innovatsionnykh proektov shkol dlia uchastiia $v$ prioritetnom natsionalnom proekte "Obrazovanie". Moscow, 5 za znaniya, 368 p.

[3] Lenin VI (1969), Imperializm kak vysshaia stadiia kapitalizma. Izdatelstvo politicheskoi literatury, Vol. 27, 387 p.

[4] Meshkov AA (1996), Osnovnye napravleniia issledovaniia innovatsii v amerikanskoi sotsiologii. Sotsiologicheskie issledovaniia, 5, pp: 117-128.

[5] Markovich DZ (1997), Obrazovanie kak resurs razvitiia. Obrazovanie: traditsiia $i$ innovatsii $v$ usloviiakh sotsialnykh peremen. Moscow, $198 \mathrm{p}$.

[6] Evreeva OA and Kochetkova LN (2016), Obrazovanie v kontekste sovremennogo sotsialnogo diskursa. Sotsialnaia politika $i$ sotsiologiia, 1(114), pp: 91.

[7] Kuzmenko GN (2011), Mirovozzrencheskie osnovaniia sotsialnykh innovatsii. Sotsialnaia politika i sotsiologiia, 5(71), pp: 13-18.

[8] Shchedrovitskii P (1998), Gorizonty innovatsionnogo dvizheniia v sovremennom otechestvennom obrazovanii \Innovatsionnoye dvizheniye $v$ rossiyskom shkol'nom obrazovanii. Moscow, Parsifal, pp: 61-78.

[9] Bystrova LI and Filippenkova AS (2017), Obshchestvo znaniia kak globalnyi rubezh mirovoi tsivilizatsii. Materialy nauchnoprakticheskoi konferentsii “Krasnovskie chteniia 2015-2016”. Ialta $99 \mathrm{p}$.

[10] Akhmedova MG, Bystrova LI, Vasiukov RV, Kaluzhskaia EV, Koval TI, Kuzmenko GN, Lobazova OF, Medvedeva GP, Melikov IM, Otiutskii GP and Skorodumova OB (2016), Filosofskie problemy sotsialnogo upravleniia. Moscow, $137 \mathrm{p}$

[11] Otiutskii GP (2014), Informatsionno-antropologicheskoe izmerenie postindustrialnogo obshchestva. SOTIS - sotsialnye tekhnologii, issledovaniia, 1 , pp: 64-81.

[12] Rezhabek EI (1995), Chto takoe postindustrializm. Innovatsionnye podkhody v nauke. Rostov-on-Don, pp: 30-31.

[13] Santo B (1990), Innovatsiia kak sredstvo ekonomicheskogo razvitiia. Moscow, $296 \mathrm{p}$.

[14] Parsons T (1994), Funktsionalnaia teoriia izmeneniia Amerikanskaia sotsiologicheskaia mysl. Moscow, 466 p.

[15] Skorodumova OB (2014), Transformatsii sistemy obrazovaniia v usloviiakh perekhoda k obshchestvu znaniia. Sbornik Filosofiia otechestvennogo obrazovaniia: istoriia i sovremennost, pp: 68-71.

[16] Skorodumova OB (2016), Transformatsiia informatsionnogo obshchestva i potrebnosti obrazovaniia. Novaia nauka: Strategii $i$ vektory razvitiia, 2-2(64), pp: 151-154.

[17] Iudina TN (2015), Integratsiia obrazovaniia i nauki kak effektivnaia osnova podgotovki sotsiologov dlia sotsialnoi sfery. Materialy Ivanovskikh chtenii, Issue 4, pp: 290-296.
[18] Zaitseva LA (2014), Filosofiia innovatsii: innovatsionnye tekhnologii - arkhitektory budushchego. Trudy Vserossiiskoi nauchnoi konferentsii "Innovatsionnye strategii razvitiia nauki tekhniki $i$ obshchestva. Sotsialnaia innovatika - 2014”. M.: VNIIgeosistem, pp: 32-36.

[19] Istrofilova OI (2014), Innovatsionnye protsessy $v$ obrazovanii. Nizhnevartovsk, Izdatelstvo Nizhnevart. gos. un-ta, $133 \mathrm{p}$.

[20] Kochetkov VV and Kochetkova LN (2009), Istoki i perspektivy globalizatsii. Sotsialnaia politika i sotsiologiia, 3, pp: 290-305.

[21] Bazilevich VD (2006), Neortodoksalnaia teoriia I.A. Shumpetera. Istoriia ekonomicheskikh uchenii. Kiev, Znanie, 1300 p. 